\title{
Conquering the experiences of pain, boredom and despair among selected incarcerated mothers through alternative learning system activities
}

\author{
Rowena Vargas Isidro ${ }^{1}$, Roberto Oberio ${ }^{2,3}$, John Paul Javero Petrola ${ }^{4,5}$ \\ ${ }^{1}$ College of Arts and Sciences, Iloilo Science and Technology University, Iloilo City, Philippines \\ ${ }^{2}$ Department of Education-District of Alimodian, Atabay Elementary School, Iloilo, Philippines \\ ${ }^{3}$ Graduate School, Guimaras State College, Guimaras, Philippines \\ ${ }^{4}$ Center for Heritage and Indigenous Cultures, University of San Agustin, Iloilo, Philippines \\ ${ }^{5}$ Department of Philosophy, College of Liberal Arts, Sciences and Education, University of San Agustin, Iloilo, Philippines
}

\begin{tabular}{l} 
Article Info \\
\hline Article history: \\
Received Jun 16, 2021 \\
Revised Nov 8, 2021 \\
Accepted Nov 22, 2021 \\
\hline
\end{tabular}

Keywords:

Alternative learning system

Arthur Schopenhauer

Incarcerated mothers

Recognition

Women's study

\begin{abstract}
This paper aims to describe the life stories and experiences of mothers in prison who have overcome their pain, boredom, and despair through the learning and recreational activities, as part of the alternative learning delivery. Analysis was done using Arthur Schopenhauer's lens. This is grounded on the idea that incarcerated mothers have experienced what Schopenhauer described as sufferings of the world which comprises the inevitable feelings of pain, boredom and despair in their entire stay at the four corners of prison cells. In this paper, face-to-face interviews, phone conversations and critical analysis in the appropriation of Schopenhauer's pessimistic concepts were employed. As a result, three themes were drawn, namely, winning over emotional and psychological anxieties, seeing the silver lining, and determination to freedom. This paper recommends to the department of education (DepEd), commission on higher education (CHED) and technical education and skills development authority (TESDA) to further extend their community services or extension function for the continuation and enhancements of the delivery of alternative learning system (ALS) among incarcerated Filipino mothers, which the society is referred to as ilaw ng tahanan (light of every home).
\end{abstract}

This is an open access article under the CC BY-SA license.

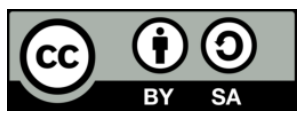

\section{Corresponding Author:}

John Paul Javero Petrola

Department of Philosophy, College of Liberal Arts, Sciences and Education, University of San Agustin

Gen. Luna St., Iloilo City 5000, Philippines

Email: jpetrola@usa.edu.ph

\section{INTRODUCTION}

This paper exposes the lived experiences and provides an analysis of the untold stories of the selected incarcerated mothers who have been away from their families for years. This paper is premised on the idea that incarcerated Filipino mothers have struggles inside their prison cells that resulted in their feelings of pain, boredom, and despair [1]. Their pains are characterized by physical and human rights abuses from their fellow inmates or from authorities managing the prisons [2]. In some cases, the pain of incarcerated mothers results from being alone and helpless because they couldn't provide for the needs of their families, especially their children [3]. On the other hand, the feelings of boredom among incarcerated mothers are brought about by having monotonous activities inside the facility and the lack of recreational activities that would help them think, discover, and create [4].

The experience of despair among incarcerated mothers were brought by their feelings of 
hopelessness because of the prolonged legal process that they had to undergo as well as the years of penalty that they had to endure in order to once again be called as free persons [5]. Furthermore, incarcerated mothers felt hopeless because they didn't see themselves as productive [6], they resorted to self-pity, experienced social shame, and guilt [7]. With these negative experiences, as what Schopenhauer called as sufferings of the world [8], incarcerated mothers need to have recreational and learning activities that will enable these mothers to realize the value of their time, their skills and improve their learning experiences despite their difficult conditions inside the prisons cells.

It is a known fact that cultural beliefs and practices have influenced child's growth and development. In the Filipino family's culture and traditions, mothers played an important role in the family especially in rearing their children to become responsible, honest, independent, and goal-oriented citizens of the country [9]. In most instances, mothers manifest great influence in the development of attitude, education, values and ethical behavior of children [10].

The Filipino context of mothers as ilaw ng tahanan or light of every home manifests the role that every mother played in their respective family and community. Being the light, Filipino mothers bring comfort, care and love to their children and family by putting their family first more than anyone or anything else. In most times, these mothers sacrifice their own needs, wants and happiness just to give the best for their families [11].

Having fully known of their roles in the family and in the society, these Filipino mothers experienced brokenness and struggles in fulfilling their sacred duties. With these said these parents who have the daunting responsibilities of raising their children were deterred in committing to their roles while being subjected to the quagmires of incarceration. Likewise, because of these superhuman obligations, incarcerated mothers had experienced inevitable sufferings while they were in prison.

According to Warner [12], the transition from being a law-abiding citizen to being an incarcerated mother is very difficult and challenging, having identified as the moral backbone of the society. This created a stigma of having a distorted character of what is considered an ideal mother in the society. The experience of imprisonment per se created mental breakdown such as anxieties, guilt and social shame, which the prisoners needed to address [13]. Terms like guilt and social shame carved in the minds of incarcerated persons.

In 2013, the United Nations' special report on violence against women stated that many countries have noted significant increase of women being incarcerated [14]. The UN enumerated various issues that incarcerated women are facing in rehabilitation centers. These issues include violence e.g., rape and prostitution, violation of privacy, inadequate health care and hygienic conditions, overcrowding, poor nutrition and lack of feminine-specific care, women with children and pregnant women, sexual orientation and gender identity, and immigration and refugee detention [14]. Being away from the comfort of their homes and from the care of their families, these physical conditions in the rehabilitation facilities added to the psychological stress and emotional stress that women in prison, especially incarcerated mothers are suffering to. However, oftentimes, these concerns were not articulated because problem brought by the stigma that the society is imposing upon the incarcerated persons. There is a need to educate the society on the realities in the life of mothers who have been put behind bars. Through this, people may fully understand the pain of being an incarcerated mother. Thus, this is a way of giving voices to the incarcerated mothers to express their experiences as well as a venue for those untold struggles of mothers in prison.

Moreover, there is the importance of providing alternative learning activities that may help incarcerated women develop a sense of positive outlook in life. Education and creating learning environment among persons deprived of liberty is necessary for these individuals to engage in critical reflection and prevent them in doing criminal acts [15]. In the Philippines, as part of education for all program, the alternative learning system (ALS) is being offered for those citizens who may have difficulty in accessing the formal schooling such as those who are considered less privileged and those behind bars [16].

Arthur Schopenhauer's [17] concept of sufferings of the world. In his seminal work titled "On the sufferings of the world", Schopenhauer argues the inevitable experiences of pain, boredom and despair. These sufferings as Schopenhauer argues are part and parcel of human life. Human existence is always coupled with constant failures in attaining one's desires for happiness. For Schopenhauer, life is a continuous process and a task to be done thus, in the entire existence of humans, they will always experience pain, boredom and despair [18].

These pessimistic concepts of Schopenhauer were appropriated in several studies. These studies provide empirical verifications of Schopenhauer's perspective of human life and human will. For one, it has provided analysis on the struggles and pressing social conditions of Ati people, an indigenous community in the Philippines. The researchers critically narrated the untold stories and lived experiences of Ati people which include physical and psychological abuses, unending issues of ancestral domain claims, and their unending struggle for self-determination [19]. 
In a study entitled "Pain, boredom and despair: the sufferings of seafarers and their families", the researchers provided analysis of the sufferings of Filipino seafarers and their families. The study showed that despite the huge number of salaries and benefits those seafarers and their families received, they still experienced sufferings which mostly stemmed from their desires of happiness, life's comfort, and satisfaction [20]. In the same study, the authors argued that having plenty of material resources is not a guarantee that human persons could escape from life's sufferings [20].

The Filipino farmers, who were considered food producers of the country, have also experienced life's sufferings. In their paper titled "Sufferings as motivation: understanding the life of farmers in Sara, Iloilo", Petrola and Ledesma appropriated Schopenhauer's concept in understanding the lives and sufferings of farmers in the Philippines. The authors argued that the experiences of landlessness, poverty, food shortage, and illnesses due to manual labor have pained them, made them suffer from despair and life's boredom [18]. However, these experiences of sufferings, frustration and disappointments pushed these Filipino farmers to work hard and have made them hopeful to achieve success in their lives [21]. The abovementioned studies simply proved the significance of Schopenhauer's unique philosophical concepts as applied in understanding the lived experiences of various sectors in the society. The present study would uniquely appropriate a better understanding of the lives, sufferings and struggles of incarcerated mothers in Iloilo, Philippines.

Furthermore, Schopenhauer argued that people will surely experience these life's inevitable sufferings of the world. However, Schopenhauer advocated the use of different forms of arts or learning activities that would stimulate persons' imagination and creativity, that would enable them to overcome their feelings of frustrations and anxieties and experience tranquility [22]. In the context of prison bars, the delivery of alternative learning system (ALS), an expanded delivery of instruction through education for all (EFA) 2015, is intended to capture those learners who haven't been in formal schooling and those who are in difficult circumstances regardless of their age and gender [23]. Through ALS, incarcerated mothers would have enabled them to overcome their pain, boredom, and despair inside the rehabilitation centers.

\section{RESEARCH METHOD}

This study was qualitative-phenomenological. Responses were taken from eight incarcerated mothers who came from different rehabilitation facilities in the Province and City of Iloilo, willingly signified to participate in this study. These conversation partners have served their prison terms and are already out of rehabilitation centers. Because of health and safety protocols in the Philippines and in Iloilo City brought about by COVID-19 pandemic, the gathering of data was done through limited face-to-face interviews, phone conversations and small focus group discussions through online modes. In the analysis of data, the researchers utilized critical and thematic analyses in the appropriation of Schopenhauer's pessimistic concepts were used. Furthermore, as part of ethical consideration, the researchers used aliases or pseudo names of the respondents. This is purposely to protect the identity of the incarcerated mothers as well as the welfare and security of their children and families. The demographic information of the participants is presented in Table 1.

Table 1. Information of research informants

\begin{tabular}{lcccccccc}
\hline Description & Informant 1 & Informant 2 & Informant 3 & Informant 4 & Informant 5 & Informant 6 & Informant 7 & Informant 8 \\
\hline Name (alias) & Jenny & Olive & Honey & Nelida & Patice & Liza & Ursula & Amanda \\
Years in prison & 5 & 5 & 4 & 3 & 5 & 5 & 5 & 3 \\
\hline
\end{tabular}

\section{RESULTS AND DISCUSSION}

\subsection{Winning over emotional and psychological anxieties}

Being away from their family for years is a struggle for incarcerated mothers. Take for instance Jenny (not her real name), a single mother and has been imprisoned for five years in the female penitentiary because of carrying illegal drugs which is a violation of Republic Act 9165 or the Comprehensive Dangerous Drugs Act of the Philippines. Jenny served her five years imprisonment and is now out of the penitentiary. Yet, she recalled how miserable her life in prison was and how she struggled with anxieties.

According to Jenny, it was 2015 where she was arrested during a buy-bust operation conducted in their place. At that time, she had a two-year-old daughter living with her. Her arrest made her anxious because of many unanswered questions in her mind like what will happen now to her child considering that she was still too small and who provided her child's needs? 
"I couldn't sleep for days, months and years because many questions are bothering me every day. Because of over thinking and stress, I became erratic inside the rehabilitation center. I couldn't eat my meals and became sickly. Sometimes, I thought of committing suicide because I couldn't bear the pain of being not with my child." (Informant 1, Jenny)

However, Jenny was thankful because of the presence of few people who she considered God sent in her most down moments. Jenny is referring to Olive and Honey (not their real names) who were Jenny's best friends in prison. For Jenny, her two best friends were the most important inmates who were also her classmates in ALS.

"Every night, we spent time together doing our assignments in school. My two best friends didn't just teach me how to write and read but also helped me develop my skills in beadworks." (Informant 1 , Jenny)

During the day, these three incarcerated mothers spent their time making simple souvenir items with the guidance of their trainers. Like Jenny, Olive and Honey were also mothers and left their children because of the crime they committed. Olive has been in prison for three years while Honey was just a year before Jenny came in. At first, Jenny was hesitant to socialize with them, but her best friends made her realize that there is still life despite their situation in prison. One of the researchers has the opportunity to interview Olive and Honey through phone.

"Being incarcerated is the most painful experience I had in my life as a woman and as mother." (Informant 2, Olive)

"Even out of prison, these painful experiences haunted us every day because of the shame that our community imposed on us. Sometimes, it came to a point that I wished to be inside the four walls of the penitentiary where I feel that I belong and valued." (Informant 3, Honey)

For them, the life outside the penitentiary is worse than that of being inside. However, the support from their fellow inmates have made them stronger women and mothers [24]. However, for Olive and Honey, inside the prison they don't experience the social shame and stigma that society is making them feel. Selfstigma among incarcerated women is associated with depression, hopelessness, low self-esteem, low social support, and social avoidance [25]. Inside the prison bars, these two argued that they were given the opportunities to express themselves and overcome their problems through art and recreational activities. Yet, as mothers they have to be strong and survive for their children and their family. By working together their projects, these two mothers were able to give esteem support to each other through motivation, encouragement, and positive assessment that helped them develop confidence despite the challenges [26]. This is a clear manifestation that despite the fact that they were deprived of liberty, activities in ALS gave them the opportunity to socialize, help each other, and appreciate their value in the community thus, gaining back their self-confidence which made them stronger women.

\subsection{Seeing the silver lining}

The life of being in prison was a life full of boredom. Nelida (not her real name) noted that their schedules in prison were dull. Nelida was imprisoned because of her involvement in illegal drugs. She was a mother of two kids. She counted every second, every minute and every day waiting for her 'free day'. During an interview, Nelida expressed her dismay and uncertainties of her situation.

"My four years stay in the penitentiary is the dreariest years of my life because the legal process was too slow for my case." (Informant 4, Nelida)

At times, she never even bothered to ask about the status of her case because she will just be frustrated once she receives 'no development' response from her lawyer and relatives.

"I missed my children every moment. I kept their pictures and posted them on my wall because I really loved them. I can't wait to be free; hug them, kiss them, cook food for them and send them to school like what I usually do. But here I am, couldn't do anything for my family. I pity myself and blame myself for what I've done." (Informant 4, Nelida)

Nelida expressed her brokenness and frustration, yet she finds hope during visitation day. She lamented that during visitation days, she felt the sense of relief. For her, these were the moments where she

Int J Public Health Sci, Vol. 11, No. 1, March 2022: 1-1x 
was able to see her close relatives and talked to her children through the phone. She finds consolation and strength being with her family and was very excited when she heard that she will be out of the prison.

Like Nelida, Patrice (not her real name) also had uncertainties in life. She felt that her three years stay in prison is the loneliest moments of her life as a mother. Being a mother to two male teenagers, she hasn't seen how her children grew up.

"This is so sad considering that they need me as they grow, and I feel bad because I couldn't be on their sides during the times, they need a mother. Instead of being proud, they would rather hate me because of the humiliation they received from their classmates since their mother is tagged as a criminal by the society." (Informant 5, Patice)

Despite these negative experiences, "I gained some confidence and self-respect because of the series of art activities that we were doing inside the prison. In fact, I still can't believe that I was able to make bead works and beautiful dolls as part of our outputs. These products were sold, and we generated income from it. The money that I gained was shared to my children to help lessen their house, personal and educational expenses." (Informant 5, Patice)

Through ALS, the incarcerated mothers were given opportunity to help financially their respective families despite being in rehabilitation center. As a result, the mothers felt sense of satisfaction and happiness in happiness that they are able to provide the needs of their families regardless of their situation [27].

\subsection{Determination to freedom}

Hopelessness was another feeling that incarcerated women were struggling with. Amanda, Ursula, and Liza (not their real names) were friends in the rehabilitation center where they stayed for three years. They are now living with their families after serving their sentences. During the small group discussion through social media, they shared how they became hopeless inside the penitentiary.

"Being incarcerated was almost equal to death because of shame that we and our families have experienced and guilt because of committing such crimes. I can't forget those sleepless nights longing for my children and worrying about their situations at home." (Informant 6, Liza)

These three former incarcerated mothers felt the loneliness and emotional struggles as well as self-pity [19].

"Every visitation day, we hide ourselves because we don't want to see our relatives. We feel guilty of what we have done. We were the reason why our families experienced humiliation and our children were bullied. At times, we wanted to die because for us living in prison was living in hell. Hell, not because of the environment inside but because of the feelings of uselessness, frustrations, insecurities of what lies in the future, and thoughts that there is no good future for us at all." (Informant 7, Ursula)

Despite these negative experiences, these incarcerated mothers proved their strong character and found consolation with each other [21].

"ALS and other skills activities have provided me the avenue of being together with my fellow inmates and doing our project as a group. This experience made me feel very happy and at least lessened my feeling of homesickness." (Informant 8, Amanda)

Every time there were activities, she felt excited since she will again be very busy doing the given tasks and learning with her friends Ursula and Liza. Because of these, they became very positive and determined to be with their families. To share the lessons they learned and show the products they made. The life stories that were shared the conversation partners showed their experiences of being in prison such as living a life away from their families, experiences of anxiety and depression, the social shame brought by the society's stigma of being called as criminals, and their struggles of living inside rehabilitation centers. Their stories of pain, boredom and despair were life's struggles that motivated them to live, continue their roles as mothers to their respective families and look forward to spending time with their families [28]. These once untold stories and difficulties have now come into the open and were overcome through the alternative learning system (ALS) being conducted inside the rehabilitation centers. Indeed, these stories show the importance of alternative learning programs as meaningful interventions to incarcerated women [29], [30]. Thus, it is with great hope that in sharing these notable stories of a few incarcerated mothers in the Philippines it will enable to solicit understanding from the people and thus, erase the society's stigma on those individuals who were deprived of liberty. 


\section{CONCLUSION}

The lived experiences of incarcerated mothers as narrated above proved the strong personality of Filipino mothers. The experiences of pain, boredom, and despair, which for Schopenhauer are inevitable sufferings in the world, have been the motivation for the once incarcerated mothers to be more positive in facing these challenges. Instead of losing hope and being discouraged, these incarcerated women used these excruciating experiences as inspiration to be a true epitome of what Filipino society's called as ilaw ng tahanan to their families and society. Relating these to Schopenhauer's concepts, life is indeed a task to be done. In human existence there's an inevitable experience of sufferings yet, it is through overcoming these sufferings that one is able to appreciate the real meaning of life. Furthermore, these incarcerated mothers, in their deep feelings of frustration and hopelessness find comfort and recognition in the presence of those people who understand them, their fellow mothers. Also, through art and recreational activities in ALS, these incarcerated mothers felt their value in the society, making them appreciate that there's still life even in prison. In this manner, Schopenhauer's concept is correct when he argues that art and recreational activities are necessary in overcoming frustrations brought by inevitable sufferings. Thus, through ALS activities provided by the facility, incarcerated mothers felt the sense of hope and freedom despite their dreadful situation inside the prison bars.

\section{ACKNOWLEDGEMENTS}

John Paul Javero Petrola is indebted to the University of San Agustin through the Office of Research and Global Relations and Center for Heritage and Indigenous Cultures for the financial assistance provided in his research activities. Dr. Isidro wishes to thank Iloilo Science and Technology University for the financial support provided in conducting her research activities. Also, Dr. Oberio thanks the Department of Education for the administrative support provided to him. Most importantly, our gratitude to our conversation partners, the incarcerated mothers who openly shared their lived experiences to us.

\section{REFERENCES}

[1] B. Crewe, S. Hulley, and S. Wright, "The gendered pains of life imprisonment," British Journal of Criminology, vol. 57, no. 6, pp. 1359-1378, Jan. 2017, doi: 10.1093/bjc/azw088.

[2] G. Fedock, S. Kubiak, R. Campbell, K. Darcy, and C. Cummings, "Prison rape reform: perspectives from women with life sentences on the impact of a class action lawsuit," Journal of Human Rights and Social Work, vol. 1, no. 3, pp. 131-142, Sep. 2016, doi: 10.1007/s41134-016-0017-9.

[3] U. Stone, M. Liddell, and M. Martinovic, "Incarcerated mothers: Issues and barriers for regaining custody of children," Prison Journal, vol. 97, no. 3, pp. 296-317, Jun. 2017, doi: 10.1177/0032885517703957.

[4] T. T. Bengtsson, "Boredom and action-experiences from youth confinement," Journal of Contemporary Ethnography, vol. 41, no. 5, pp. 526-553, Oct. 2012, doi: 10.1177/0891241612449356.

[5] K. E. Gillette, "The psychological and emotional experiences of pregnant and postpartum incarcerated women," Thesis, Smith College, 2011.

[6] S. Vanhooren, M. Leijssen, and J. Dezutter, "Ten prisoners on a search for meaning: a qualitative study of loss and growth during incarceration," Humanistic Psychologist, vol. 45, no. 2, pp. 162-178, Jun. 2017, doi: 10.1037/hum0000055.

[7] G. L. Culda, A. N. Opre, and A. C. Miu, "Short communication social support and empathy as predictors for guilt proneness in inmates," An Interdisciplinary Journal, vol. XX, no. 3, pp. 195-201, 2016.

[8] C. Smith, "Philosophical Pessimism: A Study In The Philosophy Of Arthur Schopenhauer," Thesis, Georgia State University, 2014.

[9] P. A. Schulze, "Filipino Mothers' Beliefs about parenting: a question of independence," Contemporary Issues in Early Childhood, vol. 5, no. 3, pp. 391-395, Sep. 2004, doi: 10.2304/ciec.2004.5.3.10.

[10] A. Ceka and R. Murati, "The role of parents in the education of children," Journal of Education and Practice, vol. 7, no. 5, pp. $61-64,2016$.

[11] R. M. Horne and R. S. Breitkreuz, "The motherhood sacrifice: maternal experiences of child care in the Canadian context," Journal of Family Studies, vol. 24, no. 2, pp. 126-145, May 2018, doi: 10.1080/13229400.2015.1109540.

[12] J. Warner, Perfect Madness in the Age of Anxiety. New York: Riverhead (Penguin Group, USA), 2005.

[13] A. Peckham, A woman in custody: a personal account of one nightmare journey. London: Fontana Paperbacks, 2005.

[14] R. Manjoo, "Report of the Special Rapporteur on violence against women, its causes and consequences." United Nations. 2013. https://www.ohchr.org/documents/Issues/Women/A-68-340.pdf (accessed Oct. 29, 2020).

[15] C. Behan, "Learning to escape: Prison education, rehabilitation and the potential for transformation," Journal of Prison Education and Reentry, vol. 1, no. 1, p. 20, Oct. 2014, doi: 10.15845/jper.v1i1.594.

[16] J. G. A. Pilar, "Education beyond borders: lived experiences in teaching basic english grammar among ALS teachers in Bacolod City, Philippines," Asia Pacific Journal of Multidisciplinary Research, vol. 3, no. 4, pp. 170-178, 2015.

[17] A. Schopenhauer, The Essential Schopenhauer. Great Britain: Unwin Books, 1962.

[18] J. P. J. Petrola and J. A. Ledesma, "Sufferings as motivation: understanding the life of farmers in Sara, Iloilo," International Journal of Science and Research (IJSR), vol. 7, no. 7, pp. 1218-1222, 2018, doi: 10.21275/ART2019198.

[19] J. P. Petrola, J. Ledesma, C. P. Venturillo, K. E. Del Rosario, and R. Isidro, "The will to self-determination: Understanding the life of ati people in Aklan, Philippines," Journal of Critical Reviews, vol. 7, no. 11, pp. 218-222, 2020, doi: 10.31838/jcr.07.11.35

[20] J. P. J. Petrola and R. V Isidro, "Pain, boredom and despair: the sufferings of seafarers and their familie," International Journal of Science and Research (IJSR), vol. 7, no. 7, pp. 1384-1387, 2018, doi: 10.21275/ART2019121. 
[21] J. P. J. Petrola, "Ethics of recognition: axel honneth's normative critique of modern society," Journal of Critical Reviews, vol. 7, no. 11, pp. 188-193, Jun. 2020, doi: 10.31838/jcr.07.11.30.

[22] V. A. Kayukov and B. A. Lebedev, "Schopenhauer's philosophy of music as breakthrough from the world of rationality," International Journal of Humanities and Cultural Studies (IJHCS), pp. 725-730, 2016.

[23] D. of Education, "Philippine education for All 2015 review report." 2015, 2020. https://pdf4pro.com/amp/view/philippineeducation-for-all-2015-review-report-2015-13520d.html (accessed Nov. 15, 2020).

[24] S. Clone and D. DeHart, "Social support networks of incarcerated women: Types of support, sources of support, and implication s for reentry," Journal of Offender Rehabilitation, vol. 53, no. 7, pp. 503-521, Oct. 2014, doi: 10.1080/10509674.2014.944742.

[25] M. D. Birtel, L. Wood, and N. J. Kempa, "Stigma and social support in substance abuse: Implications for mental health and wellbeing," Psychiatry Research, vol. 252, pp. 1-8, Jun. 2017, doi: 10.1016/j.psychres.2017.01.097.

[26] E. S. Valevi and L. Handayani, "Anxiety and Family Support on Infected TORCH Patients," International Journal of Public Health Science (IJPHS), vol. 3, no. 4, p. 246, Dec. 2014, doi: 10.11591/ijphs.v3i4.4699.

[27] F. Tentama, N. Z. Situmorang, and Fitrianur, "Subjective well-being among street mothers community," International Journal of Public Health Science (IJPHS), vol. 10, no. 2, pp. 370-379, Jun. 2021, doi: 10.11591/ijphs.v10i2.20615.

[28] M. C. A. Alvarez, Women, Incarceration and Drug Policies in the Philippines: Promoting Humane and Effective Responses. A Policy Guide. Quezon City: NoBox Philippines, 2018.

[29] J. B. Vicente, "Appraisal of the intervention programs for high profile inmates in the Philippines," International Journal of Advanced Research in Management and Social Sciences, vol. 8, no. 10, pp. 136-205, 2019.

[30] K. Collica-Cox and G. Furst, "Implementing Successful jail-based programming for women: A case study of planning parenting, prison \& pups-waiting to 'let the dogs in'," Journal of Prison Education and Reentry, vol. 5, no. 2, pp. 101-119, 2018, doi: 10.25771/69dq-j070.

\section{BIOGRAPHIES OF AUTHORS}

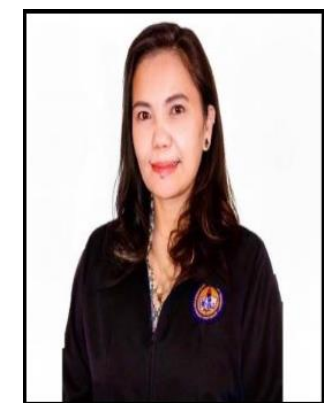

Rowena Vargas-Isidro (D) $8 \mathrm{SC}$ P is a former chair of the Social Science Department of the University of San Agustin, Iloilo City. Presently connected with Iloilo Science \& Technology University, Social Science Department. A holder of two Master's degrees in Educational management and in Social Sciences. She has completed academic requirements for the diploma in Special education. Member of different National and International Professional Organizations. Member of the RQAT VI for the Social Sciences programs. An Executive officer of the United Federation of Filipino Educators (UNIFFIED Western Visayas) and Board of Director of UNNIFIED Philippines both an affiliate of UNIFFIED, Inc., USA. He can be contacted at email: rowenaisidro3137@ gmail.com.

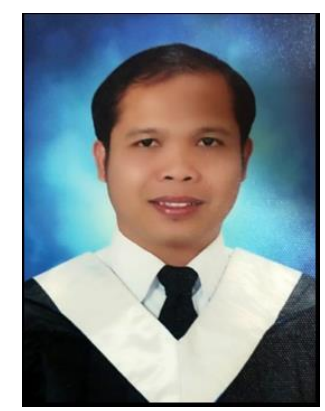

Roberto Oberio (iD 8D SC P is connected with the Department of Education as school head and a part time professor in the graduate school of Guimaras State College. He is a graduate of Bachelor of Elementary education at Central Philippine University, Master of Arts in Education in Elementary Mathematics and Doctor of Philosophy in Educational Management at West Visayas State University. $\mathrm{He}$ was chosen as a MONBUKAGAKUSHO scholar in Okayama University, Okayama Japan from 2014-2016. In 2013, he was adjudged as one of the outstanding teachers in the Schools Division of Iloilo. He serves as a trainer and resource person in Mathematics. He can be contacted at email: roberto.oberio001@deped.gov.ph.

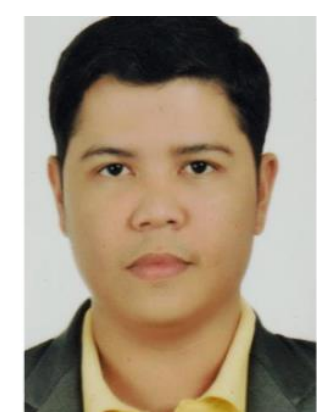

John Paul Javero Petrola (D) 8D SC P is an Associate Member, National Research Council of the Philippines (NRCP) He is a graduate of AB Philosophy from University of San Agustin (USA), Iloilo City. He holds MA in Education, major in Administration and Supervision from University of Iloilo-Phinma, Iloilo City and MA in Philosophy from Silliman University, Dumaguete City. Mr. Petrola is an Assistant Professor 4 in Philosophy in the College of Liberal Arts, Sciences and Education. As a research faculty for USA's Center of Heritage and Indigenous Cultures (CHIC), he is interested in topics on Indigenous People's (IPs) studies particularly the struggles of Ati in Panay, ethnography, critical theory, applied ethics and phenomenology. He presented papers in various conferences both in the national and international arena and published research findings in peer-refereed journals. Furthermore, Mr. Petrola has contributed inputs to the United Nation's Human Rights- Office of the High Commissioner's special rapporteur on the rights of indigenous peoples. He can be contacted at email: jpetrola@usa.edu.ph. 